ББК 81.006 .5

\title{
THE PROBLEM OF STUDYING NEOLOGISMS AND THEIR INFLUENCE ON THE ECOLOGY OF LANGUAGE
}

\author{
Shamne Nikolay Leonidovich \\ Doctor of Philological Sciences, Professor, \\ Director of Institute of Philology and Intercultural Communication, \\ Volgograd State University \\ shamnenl@gmail.com, ling@volsu.ru \\ Prosp. Universitetsky, 100, 400062 Volgograd, Russian Federation \\ Rets Irina Vladimirovna \\ Assistant, Department of English Philology, \\ Volgograd State University \\ irina_rets@bk.ru, english_philology@volsu.ru \\ Prosp. Universitetsky, 100, 400062 Volgograd, Russian Federation
}

\begin{abstract}
The article raises the issues of neology and ecolinguistics. The authors specify the criteria of ecolinguistic approach to studying neologisms based on ecolinguistic monitoring which helps to elicit factors that influence the formation of new words, spheres in which they function in language as well as to define the type of new words and number of loanwords among them. The data under analysis is compiled by about 3000 new words that appeared in English and Dutch in the last three decades. The authors elicit the main changes in the ecology of the Dutch language on different levels in the stated time frame together with the factors that motivate the formation of neologisms. Among extralinguistic factors the authors list such determinants as the emergence of new realia; scientific and technical advancement; globalization and development of the Internet. To intralinguistic factors the following are referred: linguistic economy; expressiveness of linguistic means; systematization of the vocabulary; unification of linguistic signs; conversion and the shift in stylistic usage of the words can also generate neologisms. Future development of the ecolinguistic approach in neology will help to track the evolution of modern national language and preserve its ecolinguistic balance. The research results can be used in language education, lexicographic practice or state language policy.
\end{abstract}

Key words: neologism, ecolinguistic approach, ecolinguistic monitoring, loanword, language ecology.

Language is known for its constant development with lexis being its most mobile level.

Every generation gives life to new words derived from the current reality. The electronic revolution in the second half of the twentieth century caused the scientific and technical progress to speed up, (2) and these processes were immediately reflected in language. Every year lexicographers register hundreds of new words. According to the survey carried out by Global Language Monitor, the English language obtains a new word every 98 minutes [8, p. 34].

The analysis of different linguists' viewpoints concerning the phenomenon of neologism showed 
that the definition of this term varies from author to author, but the majority of the researchers agree on the fact that neologism denotes a new word or a new meaning of the word which already exists in a language.

We define neologisms as "words or word combinations which are innovative in their form or meaning in a fixed moment in time and carrying a new social and cultural reference" $[10, \text { p. } 68]^{1}$.

The diversity of opinions about the nature, functions and classification of neologisms gives opportunities and material for new lines of linguistic research of the neonomination process.

One of such new lines of research is the study of neologisms from the perspective of ecolinguistics which we interpret as "a new research area of studying the linguistic habitat of an individual and the society aimed at eliciting the laws, principles and rules common for both the ecology and language development" [11, p. 143]. The idea that neolinguistic and ecolinguistic research works share is understanding a language as an ecosystem which can change or generate new words, alter the meanings of existing words or regulate itself. We agree with the linguist S.V. Ionova who thinks that the growing ecological crisis has served as one of the reasons for the formation of the ecolinguistic scientific paradigm: the philosophy of nature protection came to contradiction to the dominating anthropocentric ideology [5].

The ecolinguistic approach in neology should definitely include the analysis of the factors that influence the language ecosystem and give rise to new words as well as the analysis of the language spheres where these new words function. This approach also implies the type identification of new words and estimation of the number of loanwords among them. Thus, the ecolinguistic approach in neology will help to find the "unhealthy" tendencies or trends in language usage, avoid its potential contamination by neologisms-loanwords and its vulgarisation.

The ecolinguistic approach in neology can be based on ecolinguistic monitoring which we define as "a continuously functioning system of collecting and analysing extralinguistic and intralinguistic data, conducting additional information and analytical surveys (opinion polls) and estimating (detecting) the language situation and the tendencies of its further development"
$[12, p .154]$. The analysis of the findings will help to draw up the necessary measures for keeping or rehabilitating the ecolinguistic language balance.

In the course of our research 3000 new words that appeared in Dutch and English in the last three decades were selected with the help of the continuous sampling method from the following resources: the dictionaries of new words ${ }^{2}$, lists of neologisms registered annually in such leading dictionaries as Oxford Dictionary ${ }^{3}$ and Vandale Woordenboek ${ }^{4}$, collections of new words on web portals ${ }^{5}$ and "words of the year" (between the years 1990-2013). Having studied the material we revealed the cardinal changes that the Dutch language experienced in view of the active promotion of global English.

Among the extralinguistic changes we recorded the active penetration of English and American cultural realia into the Dutch language and culture (e.g. the wide-spread celebration of Halloween, St. Valentine's Day or St. Patrick's Day) and the change of spheres where English and Dutch are used by the Dutch. The spheres which are dominated by English in the Netherlands are advertising, employment and education. For example, the study of the corpus of Dutch commercial advertisements carried out by M. Gerritsen, H. Korzilius and F. van Meurs showed that $85 \%$ of the advertisements include the elements of the English language [4, p. 29]. Dutch recruitment advertisements often contain English words related to the names of professions: $H R$ manager instead of Dutch hoofd PZ 'an individual within an organization responsible for hiring new employees'; financial analyst instead of Dutch financieel analist 'an employee of a bank, brokerage, advisor, or mutual fund who studies companies and makes buy and sell recommendations'; $C E O$ instead of Dutch algemeen directeur 'the highest-ranking person in a company responsible for taking managerial decisions' etc. English also prevails over Dutch in the sphere of higher education. Since 1997 English has been used not only in the teaching practice but also in documentation management and office administration at the University of Tilburg. Dutch universities choose English to attract more foreign students. According to the researcher $\mathrm{H}$. Cohen, $80 \%$ of the graduation and $\mathrm{PhD}$ theses in Dutch universities are written in 
English. The Netherlands differ widely here from other countries where graduation papers and dissertations must be written in the national language [2, p. 150].

Among intralinguistic changes in the Dutch language ecology we revealed the changes on the phonetic, morphological, lexical and syntactic levels of the language system [9].

1. Changes on the phonetic level.

Until the second half of the twentieth century most anglicisms coined by Dutch conformed to the laws and orthoepic norms of the Dutch language. Yet our research showed that since the last three decades English words have been inclined to keep their phonetic properties in the Dutch language: Dutch show (from English show) 'performance', Dutch joggen (from English jog) 'to run as a form of physical exercise', Dutch database (from English database) 'a structured set of data' etc.

Another change on the phonetic level found in the course of our research is the change in the characteristics of some Dutch phonemes. For example, the forelingual sonorant trill Dutch consonant $[\mathrm{r}]$ is becoming backlingual and losing its vibration under the influence of the English language. Besides, the sound $[\mathrm{r}]$ is often not pronounced now in the final position in a syllable: ['amstedam] 'Amsterdam'.

Loanwords bring along new sounds to the Dutch language. For example, the letter $w$ of the Dutch alphabet corresponds to the sound [v]: weekend ['vikent] 'Saturday and Sunday' but our research showed that the neologisms that appeared in the Dutch language in the last three decades keep the English pronunciation of this sound: Windows ['windous] 'operating system (computer terminology)', website ['websait] 'an Internet location with one or more web pages' and other examples.

2. Changes on the morphological level.

Some Dutch grammatical categories have also undergone considerable changes and modified their features with the advance of the English language. Traditionally Dutch nouns acquire the plural form by adding the morpheme -en to their stem. In spite of that, the morpheme $-s$ is also used to form plural. The ending $-s$ can be found in the first place in neologisms borrowed from the English language: budgets 'financial plans, tests 'sets of questions, coaches 'a comfortable bus' etc.
Our research showed that adoption of English words with the suffixes -able and -wise led to the increase in productivity of the similar morphemes -baar, -gewijs in the Dutch language: opbelbaar 'in a working order', prestatiegewijs 'performance-wise' etc. The corpus of Dutch neologisms that we studied in the course of the research contains $7 \%$ of the new words with these suffixes.

\section{Changes on the lexical level.}

The vocabulary of each language is one of the most mobile and flexible elements of the language system, that is why the process of penetration and borrowing of foreign words is natural especially in the era of active intercultural communication. Nevertheless some Dutch linguists express a great concern about the growing number of direct unassimilated anglicisms in the Dutch language. The fact of such sharp increase is also verified by our research. We found that the corpus of Dutch neologisms under our analysis contains $40 \%$ of anglicisms, $20 \%$ out of which are direct borrowings from English [9, p. 150]. According to the linguist N. van der Sijs, English poses a major threat to the Dutch language in a way that the latter may lose its ability to adjust the imported elements [13, p. 358].

\section{Changes on the syntactic level.}

Our research showed that in comparison with other language levels the syntactic level of Dutch is the least subject to changes. The linguist L. Koenen singles out the strengthening of the economy principle which leads to modifications in the structure of the nominal group inside the Dutch sentence. The example of such changes can be the transformation of the word combination het in werking treden into de inwerkingtreding 'entering into force' [6, p. 136]. The effect of English can be found when analysing the set phrases that were borrowed from English by the Dutch language in the last three decades. Among these borrowings are such syntactic calques as $i k$ ben bang dat (derived from English I'm afraid); de...-ste ooit (from English the...ever): de warmest decembermaand ooit 'the warmest December ever'; als regel (from English as a rule) etc.

Having studied the key linguistic works on this topic we found out that most researchers don't consider the threat the English language poses to the ecology of Dutch to be fatal. One of the strong 
arguments in favor of this viewpoint is the fact that no culture can exist and develop in isolation from other cultures and language as its fundamental element cannot be kept out of these processes [1]. That is why alteration is thought to be natural for language development.

On the other hand, the threat to the ecology of the Dutch language doesn't only come from neologisms-anglicisms which are found in abundance in modern speech but primarily from the potential inability of the Dutch language to assimilate these borrowed elements. Many imported words obey the rules of the Dutch language, there are cases when borrowed lexical units are replaced by Dutch calques in the course of time as, for example, the anglicism football and the Dutch calque voetbal. However, as our research showed, the Dutch language has tended to have more and more direct unassimilated anglicisms since the last three decades which might be an alarming signal concerning its further development.

Despite the fact that ecolinguistics is aimed at protecting the health of the language it should not turn into linguistic purism which is focused on fighting against the 'language corruption'. Linguistic purism originated in the nineteenth century in response to the massive expansion of foreign vocabulary. In the twentieth century, particularly after the Second World War, the purist movement in the Netherlands turned against English. Main concern was raised over anglicisms which were understood by purists as words, expressions or constructions which conflict with Dutch structural principles: frontpagina 'front page', onderlijnen 'underline', pijplijn 'pipeline'. Some words were only rejected because their meaning expanded under English influence, like conservatief 'careful', typisch 'representative' and uitvinden 'choose'.

Anyhow, the resistance to numerous loanwords turned out to be rather ineffective. Many of the suggested replacements of anglicisms had no chance of success due to their complexity or vagueness: bulkcarrier was to be replaced by vraachtschip voor stortgoed or massa-goedschip, and bostballon was tried for airbag [7, p. 258].

As we have pointed out earlier, when analysing neologisms from the perspective of ecolinguistics it is also necessary to identify the factors which motivated the formation of new words in the language. Having studied the corpus of English and Dutch neologisms in the course of our research we found out that extralinguistic factors play the dominant role in vocabulary modification; these factors including: 1) emergence of new realia in people's life which need to be nominated; 2) scientific and technical progress; 3) globalisation and the increase in the number of people who speak English; 4) development of the Internet and popularisation of the written dialogue speech.

As our research showed it is globalisation that generated the biggest amount of neologisms in the Dutch language. In the Netherlands where over $80 \%$ of the population speaks fluent English anglicisms penetrated into all spheres of life: airconditioner (technology); aerobics (sport); allrounder (everyday language); blue jeans (clothing); bottom-up (politics) etc. Having distributed the neologisms into lexical semantic fields we found out that $31 \%$ of the new words out of total $33 \%$ in the field "computer technologies and Internet" are English loanwords.

Among the intralinguistic factors that motivate the formation of neologisms we elicited the following tendencies towards 1) linguistic economy; 2) enhancement of the expressiveness of linguistic means; 3) systematisation of the vocabulary; 4) unification of linguistic signs; 5) conversion and the shift in stylistic usage of the words.

Our research showed that the intralinguistic factors that have the greatest impact on the language vocabulary modification are the tendencies towards strengthening the economy principle and enhancing the expressiveness of linguistic means. Moreover the study of these factors in relation to English and Dutch proved there are no new words from a purist point of view. Most of them originate from the resources of each language or are borrowed from other languages.

Full-scale studies of neologisms from the perspective of ecolinguistics are vital nowadays in view of the threat that globalisation and other extralinguistic factors pose to the safety of modern national languages. Our research showed that together with a number of negative changes on all language levels neologisms also cause destandardisation of the language. Since many of 
them are loanwords neologisms lead to orthographic variability in the Dutch language that might have a negative effect on lexicographic, didactic or publishing activities: personeelsdirecteur, personeel directeur 'human resources manager' etc.

Metaphorically speaking neologisms are often referred to as "barometers" of the changes that happen in the society and the shifts in popular social tendencies [3, p. 15]. On the one hand, new words reflect public consciousness but on the other hand, they influence its development. This contradiction explains the relevance of our research work.

Further study of the conditions in which new words are generated, the details of how they function, further development of the ecolinguistic approach in neology and methods of ecolinguistic monitoring will allow to minimize the negative influence of globalization processes on the national language.

\section{NOTES}

${ }^{1}$ Hereinafter the translation from Russian was carried out by the authors of this article.

${ }^{2}$ See: Sanders E., ed. De taal van het jaar. Amsterdam-Rotterdam: Uitgeverij Prometheus, 2004. 129 p.; Tulloch S., Knowles E., Elliott J., eds. Oxford Dictionary of New Words. $2^{\text {nd }}$ ed. Oxford, Oxford University Press, 1999. 366 p.

${ }^{3}$ Stevenson A., ed. Oxford Dictionary of English. Oxford, Oxford University Press, 2010. 2112 p.

${ }^{4}$ Dale V., ed. Groot woordenboek der Nederlandse taal. Utrecht-Antwerpen, Van Dale lexicografie, 1995. 468 p.

${ }^{5}$ Word Spy. The Word Lover's Guide to New Words. Available at: http://www.wordspy.com/; NEOTERM neologismen nederlands. Available at: http://www.nlterm.org/neoterm/index.htm; Oxford Dictionaries. Language matters. Available at: http:// www.oxforddictionaries.com/; Van Dale. Available at: http://www.vandale.nl/.

\section{REFERENCES}

1. Booij G., Marle J. van. Yearbook of Morphology 2003. New York, Springer, 2010. 279 p.

2. Cohen H. Coca versus Cola: Verschillen tussen Nederland en Belgie in het gebruik van Engelse leenworden. Dordrecht, De Nieuwe Taalgids, 1996. $160 \mathrm{p}$.
3. Croft W. Social Evolution and Language Change. Manchester, University of Manchester, 2007.39 p.

4. Gerritsen M., Korzilius H., Meurs F. van. English in Dutch Commercials: Not Understood and not Appreciated. Journal of Advertising Research, 2000, no. 40 (4), pp. 17-31.

5. Ionova S.V. Osnovnye napravleniya ekolingvisticheskikh issledovaniy: zarubezhnyy i otechestvennyy opyt [Main Research Trends in Ecolinguistics: Foreign and Local Practices]. Vestnik Volgogradskogo gosudarstvennogo universiteta. Seriya 2, Yazykoznanie [Science Journal of Volgograd State University. Linguistics], 2010, no. 1 (11), pp. 86-93.

6. Koenen L., Rik S. Peptalk: De Engelse woordenschat van het Nederlands. $2^{\text {nd }}$ ed. Amsterdam, Nigh en Van Ditmar, 1992. 188 p.

7. Nejjari W., Gerritsen M., Haagen M. van der. Responses to Dutch-Accented English. World Englishes, 2012, vol. 31 (2), pp. 248-268.

8. Payack JJ.P. A Million Words and Counting. How Global English Is Rewriting the World. New York, Citadel, 2008. 224 p.

9. Rets I.V. Izuchenie novoy leksiki niderlandskogo yazyka $\mathrm{v}$ kontekste globalizatsii [Studying the New Vocabulary of the Dutch Language in the Context of Globalization]. Filologicheskie nauki. Voprosy teorii i praktiki, 2014, no. 6 (36), pp. 149-152.

10. Rets I.V. Natsionalno-kulturnaya spetsifika novoy leksiki niderlandskogo i angliyskogo yazykov [National and Cultural Specifics of New Lexis in Dutch and English]. Vestnik Volgogradskogo gosudarstvennogo universiteta. Seriya 2, Yazykoznanie [Science Journal of Volgograd State University. Linguistics], 2014, no. 1 (20), pp. 66-70.

11. Shamne N.L. Ekolingvisticheskoe issledovanie yazykovogo prostranstva polietnicheskogo regiona [Ecolinguistic Research on Language Space in Polyethnic Region]. Izvestiya Volgogradskogo gosudarstvennogo pedagogicheskogo universiteta. Seriya "Filologicheskie nauki”, 2011, no. 8, pp. 143-146.

12. Shamne N.L., Shovgenin A.N. Teoreticheskie osnovy postroeniya algoritma ekolingvisticheskogo monitoringa [Theoretical Basis of Building the Algorithm of Ecolinguistic Monitoring]. Vestnik Volgogradskogo gosudarstvennogo universiteta. Seriya 2, Yazykoznanie [Science Journal of Volgograd State University. Linguistics], 2010, no. 2(12), pp. 153-161.

13. Sijs N. van. Loanwords in the World's Languages. A Comparative Handbook. Berlin, Walter de Gruyter GmbH \& Co. KG, 2009, pp. 338-360. 


\section{К ВОПРОСУ ОБ ИЗУЧЕНИИ НОВОЙ ЛЕКСИКИ И ЕЕ ВЛИЯНИЯ НА ЭКОЛОГИЮ ЯЗЫКА}

\section{Шамне Николай Леонидович}

Доктор филологических наук, профессор, директор института филологии и межкультурной коммуникации, Волгоградский государственный университет shamnenl@gmail.com,ling@volsu.ru просп. Университетский, 100, 400062 г. Волгоград, Российская Федерация

\section{Рец Ирина Владимировна}

Ассистент кафедры английской филологии, Волгоградский государственный университет irina_rets@bk.ru, english_philology@volsu.ru просп. Университетский, 100, 400062 г. Волгоград, Российская Федерация

Аннотация. Статья посвящена вопросам неологии и эколингвистики. Авторы уточняют критерии эколингвистического подхода к изучению неологизмов, основанного на эколингвистическом мониторинге, в ходе которого выявляются факторы, обусловливающие образование новой лексики, сферы функционирования неологизмов в языке, а также определяется тип новых слов и количество среди них заимствований. Материалом для изучения послужил корпус новых слов в количестве 3000 единиц, появившихся в нидерландском и английском языках за последние три десятилетия. В рамках исследования авторы выявляют основные изменения в экологии нидерландского языка на разных его уровнях в данный хронологический период, а также факторы, мотивирующие появление неологизмов в исследуемых языках. К экстралингвистическим факторам авторы относят такие явления, как возникновение новых реалий; научно-технический прогресс; глобализация и развитие Интернета. Интралингвистические факторы, а именно: тенденции к языковой экономии, большей выразительности, систематизации словарного состава, унификации знаковых средств выражения, конверсии и изменению стилистической закрепленности единицы - также влияют на порождение неологизмов. Дальнейшая разработка эколингвистического подхода в неологии позволит проследить развитие современного национального языка и сохранить его лингвоэкологический баланс. Результаты исследования имеют теоретическую и практическую ценность и могут найти применение в лингводидактике, лексикографии, а также в сфере государственного языкового регулирования.

Ключевые слова: неологизм, эколингвистический подход, эколингвистический мониторинг, заимствование, экология языка. 